\title{
Primary metabolite kinetics of bacteriocin biosynthesis by Lactobacillus amylovorus and evidence for stimulation of bacteriocin production under unfavourable growth conditions
}

\author{
Luc De Vuyst, Raf Callewaert and Kurt Crabbé
}

Author for correspondence: Luc De Vuyst. Tel: +32 262932 45. Fax: + 3226293248.

e-mail:ldvuyst@,vnet3.vub.ac.be

Division of Industrial

Microbiology,

Fermentation Technology

and Downstream

Processing, Department of Biotechnology, Faculty of Sciences, Vrije Universiteit Brussel (VUB), Pleinlaan 2, B-1050 Brussels, Belgium

\begin{abstract}
To optimize bacteriocin production processes, the relationships between growth, bacteriocin production and factors affecting the occurrence and intensity of the activity peak during the growth cycle must be understood. Amylovorin L471, a bacteriocin produced by Lactobacillus amylovorus DCE 471, displays primary metabolite kinetics with a peak activity during the midexponential phase. Because of this growth association, only conditions favouring a drastic increase in biomass improve the volumetric bacteriocin titre. Specific bacteriocin production is enhanced under unfavourable growth conditions such as low temperatures $\left(30^{\circ} \mathrm{C}\right)$, and the presence of potentially toxic compounds such as ethanol $(1.0 \%, v / v)$ and oxygen $(80 \%$, v/v, air saturation). Whereas volumetric biomass formation and growth-associated bacteriocin production are dependent on the amount of glucose and nitrogen supplied, slow growth rates stimulate specific bacteriocin production. Bacteriocin inactivation can be ascribed to protein aggregation and adsorption phenomena. It may be overcome by switching the $\mathbf{p H}$ to $\mathbf{2 . 0}$ during the fermentation run after having reached the peak activity. Thus, manipulation of the cell environment can stimulate bacteriocin production. The latter can be induced by unfavourable growth conditions, so-called stress factors. The specific growth rate seems to play an important role in the control of bacteriocin production.
\end{abstract}

Keywords: Lactobacillus amylovorus, lactic acid bacteria, bacteriocins, amylovorin L471

\section{INTRODUCTION}

Lactic acid bacteria produce a wide variety of antagonistic factors that include primary and secondary metabolites (Piard \& Desmazeaud, 1991; De Vuyst et al., 1994b). Bacteriocins constitute an important group of antimicrobials from lactic acid bacteria (Piard \& Desmazeaud, 1992; Hoover \& Steenson, 1993; De Vuyst \& Vandamme, 1994a, b; Dodd \& Gasson, 1994). Lactic bacteriocins are bioactive peptides with a bactericidal mode of action towards other Gram-positive bacteria (Klaenhammer, 1988). Based on their physicochemical

Abbreviations: $\mathrm{AU}$, activity units; $B$, bacteriocin titre; $\mathrm{CDM}$, cell dry mass; DO, dissolved oxygen level; $S$, glucose concentration; $X$, biomass concentration; $Y_{x / s}$ cell yield coefficient; $Y_{p / x}$ bacteriocin yield coefficient. and genetic properties, they can be subdivided into four classes (Klaenhammer, 1993; De Vuyst et al., 1994b). Since many destroy food spoilage and food-borne pathogenic bacteria, the bacteriocins or the producer organisms (applied as starters or adjunct cultures) could be utilized as natural additives for food preservation in future (Ray \& Daeschel, 1992; Smith, 1993). Whether these antimicrobial proteins are primary metabolites or whether they behave as secondary metabolites is not very clear.

Primary metabolites are produced during the growth phase of an organism and play a vital role in active growth. Secondary metabolites can be described as compounds that are produced after active growth has taken place and which perform no vital function for the producing organism (Kleinkauf et al., 1986). Some secondary metabolites may however play a specific role in 
the life-cycle of a microorganism, for example during sporulation (Vandamme, 1981), mycelium formation (Kondo et al., 1988) or to defend the organism in its typical ecosystem (Hurst, 1981; Harris et al., 1992a). The two types of metabolites require different fermentation conditions and processes for maximal production.

For effective commercial application of bacteriocins, optimization of their production by environmental and technological control of the process will be necessary. Such a detailed physiological and technological study may further explain the low bacteriocinogenic activity often observed when bacteriocin-producing strains are added to food systems. The use of in situ bacteriocin production is indeed promising for a widespread and safe application of bacteriocins in future food preservation.

The effects of growth conditions have been studied for the production of nisin (Hirsch, 1951; Hurst, 1966; Egorov et al., 1971; Kozlova et al., 1972; De Vuyst \& Vandamme, 1992, 1993; De Vuyst, 1995), pediocin (Biswas et al., 1991), enterocin 1146 (Parente \& Hill, 1992; Parente \& Ricciardi, 1994), lactocin S (Mørtvedt-Abildgaard et al., 1995 ) and a number of other bacteriocins (Barefoot \& Klaenhammer, 1984; Joerger \& Klaenhammer, 1986; Muriana \& Klaenhammer, 1987; Daba et al., 1993; Kaiser \& Montville, 1993; Parente et al., 1994; Quadri et al., 1994). Maximum bacteriocin production usually requires complex media and well-controlled physical factors such as temperature and $\mathrm{pH}$. Unfortunately, most bacteriocins show a more or less sharp decrease in activity at the end of the exponential growth phase (Barefoot \& Klaenhammer, 1984; Joerger \& Klaenhammer, 1986; Muriana \& Klaenhammer, 1987; De Vuyst \& Vandamme, 1992; Daba et al., 1993; Parente et al., 1994). However, a decrease in activity has not been observed for all bacteriocins from lactic acid bacteria, even after prolonged incubation. Therefore it is necessary to understand the relationships between growth, bacteriocin production and factors affecting the occurrence and intensity of the activity peak during the growth cycle of the producing strains. Consequently, metabolic and process control of bacteriocin biosynthesis to enhance their production, activity and stability may have economic significance for bacteriocin production processes.

Amylovorin L471 is a bacteriocin that is produced by a Lactobacillus amylovorus strain (L. De Vuyst, R. Callewaert $\&$ B. Pot, unpublished results). It is a small, thermostable and extremely hydrophobic antimicrobial protein displaying antagonistic activity towards closely related strains such as Lactobacillus delbrueckii subsp. bulgaricus LMG 6901T (the most sensitive strain), L. delbrueckii subsp. delbrueckii ATCC 6949 and Lactobacillus belveticus ATCC 15009. Under native conditions, the bacteriocin forms aggregates, the molecular mass of which exceeds $30 \mathrm{kDa}$. Under reduced conditions, two peptide bands can be visualized by tricine-SDS-PAGE, both with a molecular mass of less than $6000 \mathrm{Da}$.

In this paper the primary metabolite kinetics of amylovorin L471 biosynthesis are described under different physiological conditions. Furthermore, it is shown that bacteriocin production can be induced by unfavourable growth conditions, so-called stress factors, and that the specific microbial growth rate seems to play an important role in the control of bacteriocin production.

\section{METHODS}

Bacterial strains and media. The bacteriocin-producing strain used in this study was L. amylovorus DCE 471. L. delbrueckii subsp. bulgaricus LMG $6901 \mathrm{~T}$ was used as the amylovorinsensitive indicator organism. The strains were stored at $-80^{\circ} \mathrm{C}$ in MRS broth plus $25 \%(\mathrm{v} / \mathrm{v})$ glycerol. Before experimental use, the cultures were propagated twice in MRS (Oxoid) at $37^{\circ} \mathrm{C}$; the transfer inoculum was $1 \%(\mathrm{v} / \mathrm{v})$. MRS, TGS (Trypton Glucose Salts) and LHGS (Lactalbumin Hydrolysate Glucose Salts) broth were used for bacteriocin production. TGS broth contains $\left(\mathrm{g} \mathrm{l}^{-1}\right)$ : glucose, 20; tryptone (Oxoid), 20; $\mathrm{Na}_{2} \mathrm{HPO}_{4}, 6 ; \mathrm{KH}_{2} \mathrm{PO}_{4}, 3 ; \mathrm{NH}_{4} \mathrm{Cl}, 1 ; \quad \mathrm{MgSO}_{4}, 0.245 ;$ $\mathrm{MnSO}_{4} . \mathrm{H}_{2} \mathrm{O}, 0 \cdot 04 ; \mathrm{CaCl}_{2}, 0 \cdot 015$; plus $1 \mathrm{ml}$ Tween $80 \mathrm{l}^{-1}$. LHGS has the same composition as TGS except that tryptone is replaced by an equal amount of lactalbumin hydrolysate (Oxoid). Agar media were prepared by the addition of $1.5 \%$ $(\mathrm{w} / \mathrm{v})$ granulated agar (Oxoid) to the broth medium; overlay agar contained $0.7 \%$ granulated agar.

Fermentation experiments. A 6.41 Biostat E fermenter (B. Braun Biotech International) containing 5.5 1 MRS broth was used to study the kinetics of amylovorin production. The growth medium was adjusted to $\mathrm{pH} 6.5$ and sterilized at $121{ }^{\circ} \mathrm{C}$. The carbon source (glucose) was sterilized separately and aseptically added to the fermenter. The fermenter was inoculated with $50 \mathrm{ml}$ (approx. 1\%, v/v) of an exponentially growing culture of the amylovorin-producing strain L. amylovorus DCE 471. The inoculum was obtained by propagating a fresh culture twice at $37^{\circ} \mathrm{C}$ for $12 \mathrm{~h}$. The fermenter was operated at $37^{\circ} \mathrm{C}$ (or the temperature indicated) without aeration. Slow agitation (50 r.p.m.) was maintained to keep the fermentation broth homogeneous. Experiments in which growth and bacteriocin production were examined under aerobic conditions were performed in a stainless steel, in-situ-sterilizable Braun Biostat $C$ fermenter (working volume, $12 \mathrm{l}$ ) with $\mathrm{pH}$ and dissolved oxygen (DO) control. Oxygen was supplied by adding sterile filtered air; constant saturation was achieved by automatic control of the air flow rate. Experiments in Erlenmeyer flasks $(250 \mathrm{ml})$ involved the addition of sterile ethanol (final concentration $0 \cdot 0$, $1 \cdot 0,2.0$ or $3.0 \%, \mathrm{v} / \mathrm{v}$ ) or sodium chloride (final concentration $0 \cdot 0,0 \cdot 5,1 \cdot 0,2 \cdot 0$ or $3 \cdot 0 \%, \mathrm{w} / \mathrm{v}$ ) solutions to $100 \mathrm{ml} \mathrm{MRS} \mathrm{broth,}$ before inoculation with $L$. amylovorus DCE 471. All fermentations were done in duplicate.

Sampling. Over a period of $24 \mathrm{~h}$ or more, samples were aseptically withdrawn from the fermentation vessel to determine cell number (c.f.u.), cell dry mass (CDM), bacteriocin activity $(B)$ and residual glucose concentration $(S)$. DO, $\mathrm{pH}$ and base supply were monitored on line. Cells were removed from samples to be assayed for bacteriocin activity and residual glucose concentration by centrifugation $\left(5000 \mathrm{~g}, 20 \mathrm{~min}, 4^{\circ} \mathrm{C}\right)$. Adsorption and desorption of the bacteriocin molecules from the cells of the producing organism were studied using the technique of Yang et al. (1992). Proteolytic activity of cells and cell-free supernatants during fermentation was tested using azocasein as described by Parente et al. (1994)

Growth determination. CDM determinations were performed by filtering $50 \mathrm{ml}$ fermentation broth through $0.45 \mu \mathrm{m} \mathrm{HA}$ filters (Millipore) and drying at $105^{\circ} \mathrm{C}$ for $24 \mathrm{~h}$. Cell numbers were estimated by plate counts on MRS agar. The maximal 
specific growth rate $\left(\mu_{\max }\right)$ was calculated by linear regression from plots of $\ln X$ versus $t$ (where $X$ is the biomass concentration in $\mathrm{g} \mathrm{CDM} \mathrm{l}^{-1}$ and $t$ the time) at points during the exponential growth phase. Cell yields $\left(Y_{x / s}\right)$ were calculated by linear regression from plots of $X-X_{0}$ versus $S_{0}-S$ (where $X$ is the biomass concentration in $\mathrm{g} \mathrm{CDM} \mathrm{l}^{-1}$ and $S$ the residual glucose concentration in $\mathrm{g} \mathrm{l}^{-1}$ ).

Quantitative determination of bacteriocin titres. Amylovorin L471 activity was determined by an adaptation of the critical dilution method currently used for the assay of bacteriocins (Mayr-Harting et al., 1972). Serial twofold dilutions of filtersterilized cell-free culture supernatant containing bacteriocin $(10 \mu \mathrm{l})$ were spotted onto fresh indicator lawns of $L$. delbrueckii subsp. bulgaricus LMG 6901T. These lawns were prepared by propagating fresh cultures to $\mathrm{OD}_{600} 0.45$ and adding $100 \mu \mathrm{l}$ cell suspension to $3.5 \mathrm{ml}$ overlay agar. Overlaid agar plates were incubated for at least $24 \mathrm{~h}$ at $37^{\circ} \mathrm{C}$. Activity was defined as the reciprocal of the highest dilution demonstrating complete inhibitory activity of the indicator lawn and was expressed in activity units (AU) ( $\mathrm{ml}$ culture medium) ${ }^{-1}$. Bacteriocin yields $\left(Y_{p / x}\right)$ were calculated by linear regression from plots of $B-B_{0}$ versus $X-X_{0}$ (where $B$ is the bacteriocin titre in $\mathrm{AU}(\mathrm{gCDM})^{-1}$

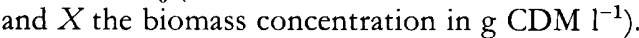

Glucose concentration determination. Residual glucose levels were determined using a YSI model 27 biosensor (Yellow Springs Instrument Company).

\section{RESULTS}

\section{Dynamics of amylovorin L471 production in batch cultivation}

To determine the relationship between growth and bacteriocin production, and also the optimal temperature for production of amylovorin L471, L. amylovorus DCE 471 was grown in a fermenter at temperatures of 30,37 and $45^{\circ} \mathrm{C}$ at controlled $\mathrm{pH} 5 \cdot 0$. The time course of growth, bacteriocin production and substrate consumption are shown in Fig. 1. Amylovorin L471 was first detected early in the exponential growth phase and was produced continuously during this phase supporting the proposal that bacteriocins display primary metabolite kinetics (De Vuyst \& Vandamme, 1992). Bacteriocin activity showed a maximum level during the midexponential phase and then decreased rapidly. Relatively sharp maxima occurred after $20 \mathrm{~h}$ at $30^{\circ} \mathrm{C}(3200$ $\left.\mathrm{AU} \mathrm{m}{ }^{-1}\right)$, after $12 \mathrm{~h}$ at $37^{\circ} \mathrm{C}\left(6400 \mathrm{AU} \mathrm{ml}^{-1}\right)$ and after $6 \mathrm{~h}$ at $45^{\circ} \mathrm{C}\left(3200 \mathrm{AU} \mathrm{ml}^{-1}\right)$. Biomass yields based on the amount of $\mathrm{NaOH}$ required to neutralize the lactic acid accumulated and hence the amount of glucose consumed (homofermentation) were estimated by linear regression from the plots of $X-X_{0}$ versus $S_{0}-S$ (where $X$ is the biomass concentration in $\mathrm{g} \mathrm{CDM} \mathrm{l^{-1 }}$ and $S$ the residual glucose concentration in $\mathrm{g} \mathrm{l}^{-1}$; Fig. 2). Yields were constant and independent of time for a given temperature and increased from $0.12 \pm 0.01 \mathrm{~g} \mathrm{~g}^{-1}$ at $30^{\circ} \mathrm{C}\left(r^{2} 0.993\right)$ and $45^{\circ} \mathrm{C}\left(r^{2} 0.982\right)$ to $0.15 \pm 0.01 \mathrm{~g} \mathrm{~g}^{-1}$ at $37^{\circ} \mathrm{C}\left(r^{2} 0.995\right)$. The highest final biomass $\left(2 \cdot 05 \mathrm{~g} \mathrm{CDM} \mathrm{l}^{-1}\right)$ was obtained at $37^{\circ} \mathrm{C}$ (Fig. 1). That the bacteriocin was produced as a primary metabolite was confirmed by plots of the bacteriocin product yield showing the change in bacteriocin activity $\left(B-B_{0}\right)$ as a function of biomass formation $\left(X-X_{0}\right)$ (Fig. 3.). The straight lines with positive slope indicated an increasing yield of bacteriocin per unit of cell mass during the active growth phase. Although the highest volumetric activity level was found during fermentation at $37^{\circ} \mathrm{C}$, the specific bacteriocin production was experimentally determined as $4.5 \pm 1.4 \times 10^{6}$, $3.0 \pm 0.3 \times 10^{6}$ and $3 \cdot 8 \pm 0.9 \times 10^{6} \mathrm{AU}(\mathrm{g} \mathrm{CDM})^{-1}$ at 30,37 and $45^{\circ} \mathrm{C}$, respectively. The maximal specific growth rates were calculated as $0.14,0.54$ and $0.72 \mathrm{~h}^{-1}$ at 30,37 and $45{ }^{\circ} \mathrm{C}$, respectively (Fig. 1). This indicates that bacteriocin production - in particular the specific bacteriocin production - was stimulated by temperatures unfavourable for growth, particularly low temperatures that are characterized by a very slow growth rate. Slow growth seems to induce a stress response in the bacteria, resulting in more efficient bacteriocin production. Similar results were found in batch cultivations without $\mathrm{pH}$ control. In addition, under uncontrolled $\mathrm{pH}$ conditions it was observed that a lower temperature coincided with a higher maximum bacteriocin titre achieved during the cell growth cycle $\left(12800,3200\right.$ and $800 \mathrm{AU} \mathrm{ml}^{-1}$ at 30,37 and $45^{\circ} \mathrm{C}$, respectively).

The rate of decrease of bacteriocin activity was not temperature-dependent (Fig. 1). However, the decrease in bacteriocin activity levels was much more pronounced in $\mathrm{pH}$-controlled fermentations in comparison with an uncontrolled $\mathrm{pH}$-fermentation profile (unpublished results). Several mechanisms can be responsible for the decrease of bacteriocin activity (De Vuyst \& Vandamme, 1992) of which protein aggregation, proteolytic degradation by specific or non-specific proteases, and bacteriocin adsorption to the cells may be the most important ones. Aggregation of individual polypeptide chains as well as formation of complexes with other medium constituents does occur as could be revealed by diafiltration experiments and chromatographic analysis (L. De Vuyst, R. Callewaert \& B. Pot, unpublished results). However, denaturing agents such as SDS and urea did not enhance bacteriocin activity (unpublished results), as was shown for helveticin J by Joerger \& Klaenhammer (1986). Proteolytic activity was assayed on both cells and cell-free culture supernatants using azocasein as a substrate. No proteolytic activity could be detected with this non-specific substrate. The change in $A_{350}$ was negligible and varied from 0.11 to 0.12 in at least $180 \mathrm{~min}$ with cell-free culture supernatant and remained constant $(0 \cdot 08)$ in the presence of the cells. The controls containing 175, 17.5 or $1.75 \mathrm{U} \alpha$-chymotrypsin $\mathrm{ml}^{-1}(50 \mathrm{mM}$ sodium phosphate buffer, $\mathrm{pH} 7.5$ ) showed an increase in $A_{350}$ from 0.406 to $0 \cdot 818$, from $0 \cdot 180$ to $0 \cdot 650$, and from 0.093 to $0 \cdot 360$, respectively.

Adsorption/desorption flask experiments using the technique of Yang et al. (1992) showed a possible adsorption of the bacteriocin molecules to producing cells at $\mathrm{pH}>2 \cdot 0$, although adsorption to the walls of the recipient cannot be excluded. However, after adsorption, almost no bacteriocin activity potentially adsorbed could be released from the cells in flask experiments. In contrast, when fermentations were run at controlled pH 5.0 and at $37^{\circ} \mathrm{C}$, sample culture supernatants both adjusted to $\mathrm{pH} 2.0$ and adjusted to $\mathrm{pH} 2 \cdot 0$ followed by boiling of the sample, 

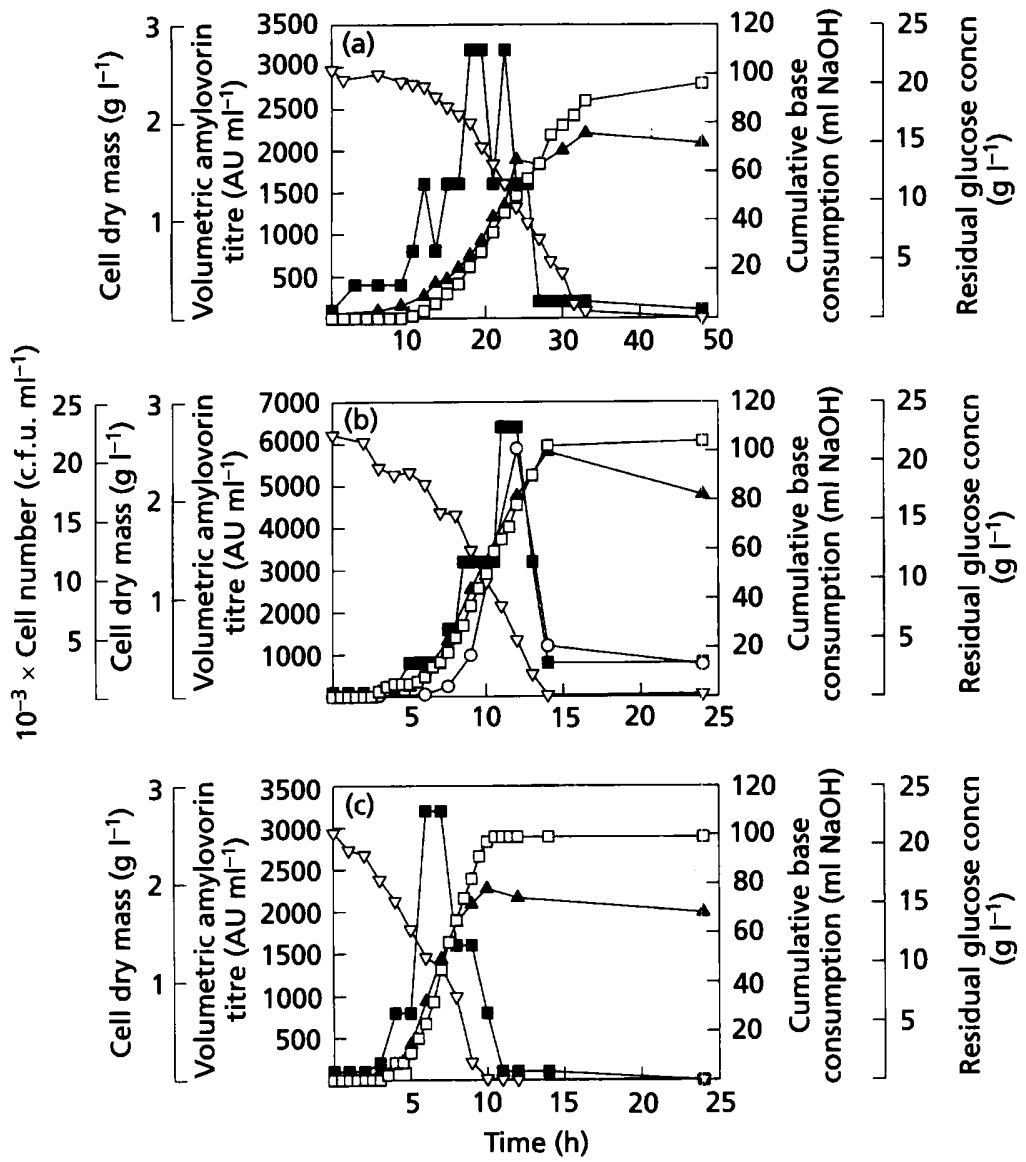

Fig. 1. Batch fermentation profile of $L$. amylovorus DCE 471 growth and amylovorin L471 production at constant $\mathrm{pH} 5.0$ at $30^{\circ} \mathrm{C}$ (a), $37^{\circ} \mathrm{C}$ (b) and $45^{\circ} \mathrm{C}$ (c). Cells were grown in a Biostat $E$ fermenter containing 5.5। MRS

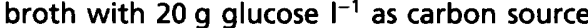
(see Methods). O, Cell numbers (only shown for $\left.37^{\circ} \mathrm{C}\right) ; \boldsymbol{A}$, cell dry mass; $\boldsymbol{Q}$, volumetric amylovorin L471 titre; $\nabla$, residual glucose concentration: $\square$, base consumption. Note the differences in the time scale on the $x$ axis between (a), (b) and (c), and also the variation in the $y$-axis scale showing bacteriocin activity.

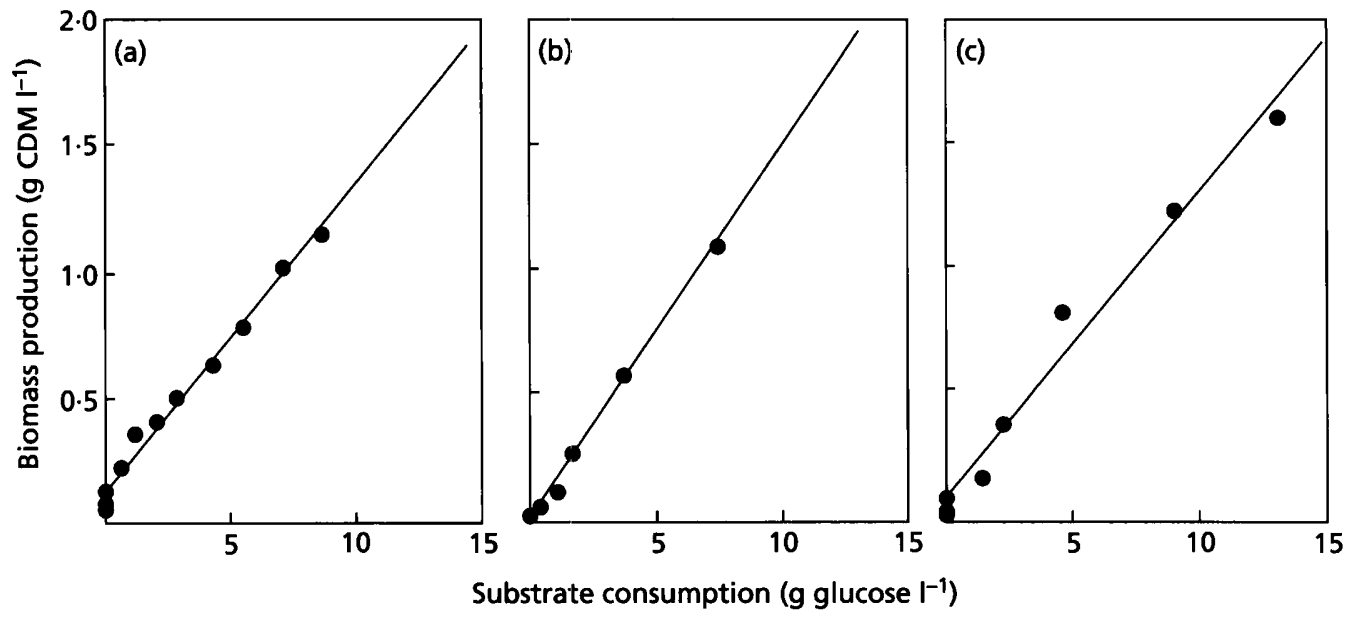

Fig. 2. Relationship between biomass production $\left(X-X_{0}\right)$ and substrate consumption $\left(S_{0}-S\right)$ during batch cultivation of $L$. amylovorus DCE 471 in MRS broth with $20 \mathrm{~g}$ glucose $\mathrm{l}^{-1}$ at controlled pH 5.0 at $30^{\circ} \mathrm{C}(\mathrm{a}), 37^{\circ} \mathrm{C}$ (b) and $45^{\circ} \mathrm{C}$ (c).

showed a higher bacteriocin activity level (measured after adjustment to $\mathrm{pH} 6.5$ ) compared to non-treated samples (Fig. 4a). Furthermore, during fermentations run at $37^{\circ} \mathrm{C}$ and at controlled $\mathrm{pH} 5.0$ during the active bacteriocin production phase, followed by a switch to $\mathrm{pH} 2 \cdot 0$ by automatic addition of $2 \mathrm{M} \mathrm{HCl}$ when bacteriocin production reached its peak, the activity detected in cell-free culture supernatants remained approximately constant. This resulted in a bacteriocin titre plateau at an activity of approximately $3200 \mathrm{AU} \mathrm{ml}^{-1}$ (Fig. 4b). 


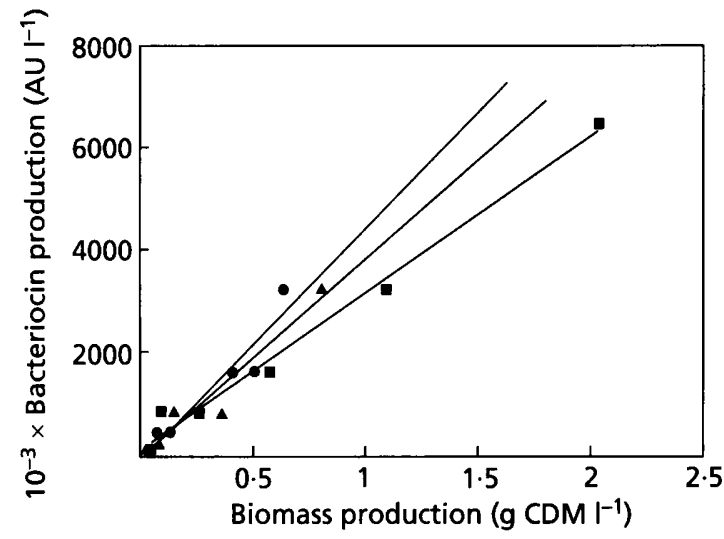

Fig. 3. Relationship between bacteriocin production $\left(B-B_{0}\right)$ and biomass formation $\left(X-X_{0}\right)$ during batch cultivation of $L$. amylovorus DCE 471 in MRS broth with $20 \mathrm{~g}$ glucose $\mathrm{I}^{-1}$ at controlled $\mathrm{pH} 5.0$ at $30^{\circ} \mathrm{C}(\mathbf{O}), 37^{\circ} \mathrm{C}(\boldsymbol{\square})$ and $45^{\circ} \mathrm{C}(\boldsymbol{\Delta})$.
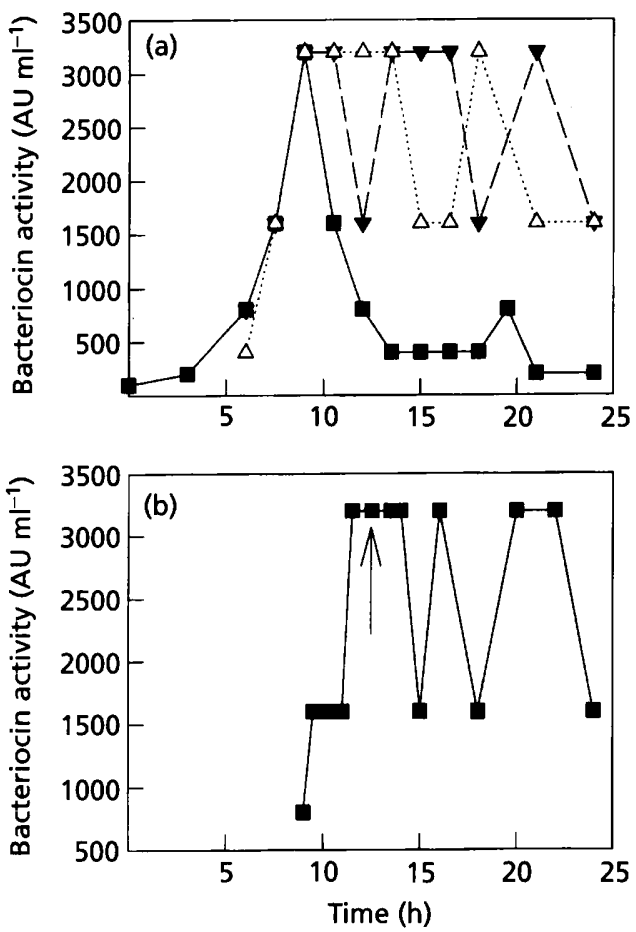

Fig. 4. Production and activity of amylovorin L471 produced by $L$. amylovorus DCE 471 with time in a Biostat $C$ fermenter

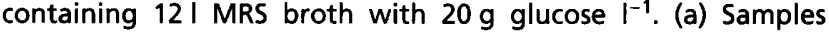
were taken from a fermentation controlled at a constant $\mathrm{pH}$ of 5.0. Bacteriocin activity was assayed on cell-free culture supernatants adjusted to $\mathrm{pH} 6.5$ ( $(\mathbf{D})$, culture supernatants adjusted to $\mathrm{pH} 2.0$ followed by centrifugation and adjusting the cell-free liquor back to $\mathrm{pH} 6.5(\triangle)$, and culture supernatants adjusted to $\mathrm{pH} 2.0$ followed by boiling for $5 \mathrm{~min}$ at $100^{\circ} \mathrm{C}$, centrifuging and adjusting the cell-free liquor back to $\mathrm{pH} 6.5$ $(\nabla)$. (b) The fermentation was controlled at a constant $\mathrm{pH}$ of 5.0 during the phase of active cell growth and bacteriocin production, and at a constant $\mathrm{pH}$ of 2.0 after having reached the bacteriocin peak activity. The arrow indicates the switch from $\mathrm{pH} 5.0$ to 2.0 performed by automatic addition of $2 \mathrm{M} \mathrm{HCl}$. , Bacteriocin activity.
Decreases in bacteriocin activity were concomitant with decreases in cell numbers (see Figs $1 \mathrm{~b}$ and 6a), apparently indicating cell death. The $\mathrm{OD}_{600}$ did not decrease indicating that no cell lysis occurred.

\section{Nutritional control of amylovorin L471 production in batch fermentations}

Influence of initial glucose levels. When L. amylovorus DCE 471 was grown in MRS broth (containing $20 \mathrm{~g}$ glucose $1^{-1}$ ) without $\mathrm{pH}$ control, amylovorin L471 production was limited by the low $\mathrm{pH}$, although glucose seemed to be sufficiently available. Under $\mathrm{pH}$-controlled fermentation conditions ( $\mathrm{pH} 5.0$ or 5.4 ) higher cell densities and hence amylovorin titres were reached. However, growth ceased after $12 \mathrm{~h}$ of fermentation, because no glucose remained (L. De Vuyst, R. Callewaert \& B. Pot, unpublished results). In order to prolong the exponential growth phase and hence the maximal cell density and concomitantly the amylovorin titre, fermentations were carried out at $37^{\circ} \mathrm{C}$ and constant $\mathrm{pH}(5 \cdot 0)$ with increasing initial glucose concentrations of $5,20,30,40$ and $60 \mathrm{~g} \mathrm{l}^{-1}$. The data are shown in Table 1 . The bacteriocin activity seemed to reach a plateau value with an activity of $6400 \mathrm{AU} \mathrm{ml}^{-1}$, except for the fermentation with an initial glucose concentration of $30 \mathrm{~g} \mathrm{l}^{-1}$. This may indicate carbon source regulation (De Vuyst \& Vandamme, 1992), end product inhibition (Ten Brink et al., 1994) and/or deficient bacteriocin biosynthesis owing to lack of a nutrient other than glucose. After about $10 \mathrm{~h}$ of growth the fermentation liquor contained maximal bioactivities in most cases. Upon further fermentation bacteriocin production stopped in those initially containing 30,40 and $60 \mathrm{~g}$ glucose $\mathrm{1}^{-1}$ despite the high residual glucose levels. Similar growth rates (calculated as $0.54 \mathrm{~h}^{-1}$ ) were observed for all initial glucose concentrations. However, the specific bacteriocin production was significantly higher at $60 \mathrm{~g}$ initial glucose $1^{-1}\left[8 \cdot 9 \pm 3.8 \times 10^{6} \mathrm{AU}(\mathrm{g} \mathrm{CDM})^{-1}\right]$ compared to the other glucose levels $\left[3.0 \pm 1.2 \times 10^{6}, 2.5 \pm 0.3 \times 10^{6}\right.$ and $2 \cdot 9 \pm 0.4 \times 10^{6} \mathrm{AU}(\mathrm{g} \mathrm{CDM})^{-1}$ for $0.5,3.0$ and $4.0 \%$ (w/v) glucose, respectively], as calculated from the plots of the change in bacteriocin activity $\left(B-B_{0}\right)$ as a function of $\left(X-X_{0}\right)$ (Fig. 5). This high glucose level may have caused a stress condition for the producing cells. Whereas the total biomass increased from $0.95 \mathrm{~g} \mathrm{CDM} \mathrm{l}^{-1}$ at $5 \mathrm{~g}$ initial

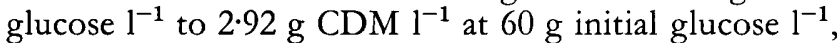
the maximal bioactivity always corresponded with a biomass of approximately $1.50 \mathrm{~g} \mathrm{CDM} \mathrm{l}^{-1}$ (except for $5 \mathrm{~g}$ glucose $1^{-1}$ where the maximum biomass level did not reach this value owing to the limited glucose supply). During the stationary phase the culture consumed glucose and produced lactic acid at a constant rate (data not shown), indicating that exhaustion of some other nutrient was responsible for the ending of growth and its associated amylovorin L471 production.

Influence of $\mathrm{C} / \mathrm{N}$ ratio. To determine whether nitrogen was a limiting factor, amylovorin production was studied with varying $\mathrm{C} / \mathrm{N}$ ratios in the fermentation broth using the semisynthetic TGS medium (Table 2). Because the biomass concentration did not double with an increasing glucose concentration, no improved bacteriocin yield 
Table 1. Influence of initial glucose concentration on L. amylovorus DCE $\mathbf{4 7 1}$ growth and amylovorin L471 production in fermentations at controlled $\mathrm{pH} 5.0$

Fermentations were run in a fermenter containing 5.5 1 MRS broth (see Methods).

\begin{tabular}{|c|c|c|c|c|c|c|}
\hline $\begin{array}{l}\text { Glucose } \\
\text { concn } \\
\left(\mathrm{g} \mathrm{1}^{-1}\right)\end{array}$ & $\underset{\left(\mathrm{h}^{-1}\right)^{*}}{\mu_{\max }}$ & $\begin{array}{c}\text { Length of } \\
\text { exponential } \\
\text { phase (h) }\end{array}$ & $\begin{array}{c}X \\
\left(\mathrm{~g} \mathrm{CDM} \mathrm{1}^{-1}\right) \dagger\end{array}$ & $\begin{array}{c}B_{\max } \\
\left(\mathrm{AU} \mathrm{ml}^{-1}\right)\end{array}$ & $\begin{array}{c}\text { Time of } B_{\max } \\
\text { (h) }\end{array}$ & $\begin{array}{c}\times 10^{-3} Y_{p / x} \\
{\left[\mathrm{AU}(\mathrm{g} \mathrm{CDM})^{-1}\right]}\end{array}$ \\
\hline $5 \cdot 0$ & 0.53 & 12 & 0.95 & 1600 & $7 \cdot 5$ & 3000 \\
\hline $20 \cdot 0$ & 0.54 & 12 & $2 \cdot 05$ & 6400 & $11-12$ & 3000 \\
\hline $30 \cdot 0$ & $0.45 \ddagger$ & 14 & $2 \cdot 35$ & 4500 & $10-12 \cdot 5$ & 2600 \\
\hline $40 \cdot 0$ & $0.39 \ddagger$ & 14 & $2 \cdot 60$ & 6400 & $10-12$ & 2900 \\
\hline $60 \cdot 0$ & 0.54 & 18 & $2 \cdot 92$ & 6400 & 8-9 & 8900 \\
\hline
\end{tabular}

* Calculated from CDM determinations during the exponential growth phase.

+ Biomass concentration at the end of the exponential phase.

$\ddagger$ No linearity was observed in the plot of $\ln X$ versus $t$.

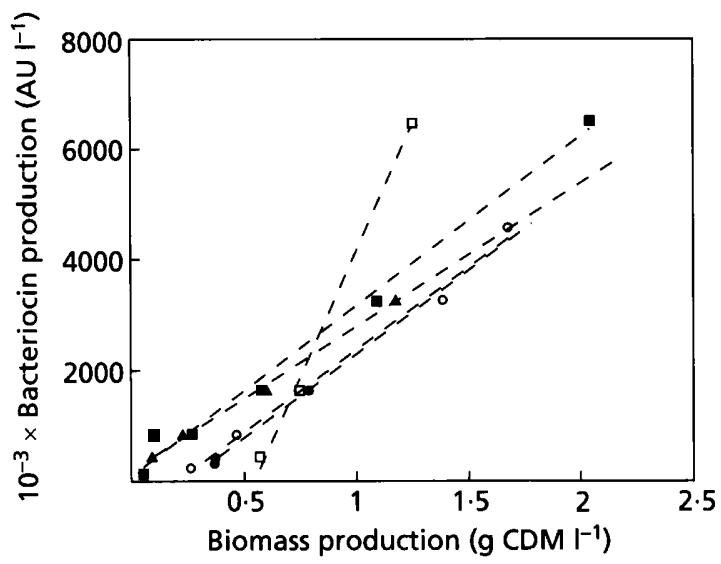

Fig. 5. Relationship between bacteriocin production $\left(B-B_{0}\right)$ and biomass formation $\left(X-X_{0}\right)$ during batch cultivation of $L$. amylovorus DCE 471 in MRS broth at controlled $\mathrm{pH} 5.0$ and $37^{\circ} \mathrm{C}$ with increasing initial glucose concentrations of $5.0(\mathrm{O})$, $20.0(\square), 30.0(\Delta), 40.0(0)$ and $60.0(\square) \mathrm{g} \mathrm{I}^{-1}$. could be detected by the bacteriocin assay (powers of two) used. Only conditions favouring a drastic increase in biomass concomitantly improved bacteriocin titres. As shown in Table 2, biomass production is dependent on glucose supply and, because of its association with growth, so too is bacteriocin production.

\section{Influence of initial nitrogen concentration and other growth} factors. In an attempt to further increase growth and bacteriocin production, L. amylovorus DCE 471 was cultivated at $\mathrm{pH} 5.0$ in MRS broth containing a double amount of total nitrogen $(4.4 \%)$ and hence unknown growth factors (e.g. vitamins and minerals derived from yeast extract). No higher bioactivity (6400 $\mathrm{AU} \mathrm{ml}^{-1}$ ) could be detected (Table 2 ); the total biomass yield was 1.3-fold higher than before. The maximal bioactivity was reached after about $10 \mathrm{~h}$ of fermentation and corresponded with a biomass of approximately $2 \cdot 10 \mathrm{~g} \mathrm{CDM} \mathrm{l}^{-1}$ (data not shown). Fermentation in MRS broth containing fourfold higher total initial nitrogen concentration $(8 \cdot 8 \%)$

Table 2. Influence of medium composition on L. amylovorus DCE 471 growth and amylovorin L471 production at controlled $\mathrm{pH} 5.0$

Fermentations were run in a fermenter containing 5.5 (MRS) or 12 (TGS, LHGS) 1 culture broth (see Methods).

\begin{tabular}{|c|c|c|c|}
\hline Medium composition & $\begin{array}{l}\mu_{\max } \\
\left(\mathbf{h}^{-1}\right)\end{array}$ & $\frac{X_{\max }}{\left(\mathrm{g} \mathrm{CDM}^{-1}\right)}$ & $\begin{array}{c}B_{\max } \\
\left(A U \mathrm{ml}^{-1}\right)\end{array}$ \\
\hline TGS broth $(1.0 \%$ glucose, $2.0 \%$ tryptone $)$ & $0 \cdot 26$ & 0.63 & 1600 \\
\hline TGS broth $(2.0 \%$ glucose, $2 \cdot 0 \%$ tryptone $)$ & ND & 0.78 & 1600 \\
\hline TGS broth ( $2.0 \%$ glucose, $4.0 \%$ tryptone) & ND & $0 \cdot 99$ & 1600 \\
\hline $\begin{array}{l}\text { LHGS broth }(2 \cdot 0 \% \text { glucose, } 2 \cdot 0 \% \\
\text { lactalbumin hydrolysate })\end{array}$ & ND & $0 \cdot 16$ & 800 \\
\hline MRS broth $(2.0 \%$ glucose, $2.2 \%$ nitrogen $)$ & 0.54 & $2 \cdot 05$ & 6400 \\
\hline MRS broth ( $2.0 \%$ glucose, $4.4 \%$ nitrogen $)$ & $0 \cdot 52$ & $2 \cdot 59$ & 6400 \\
\hline MRS broth ( $4.0 \%$ glucose, $8.8 \%$ nitrogen) & $0 \cdot 47$ & $5 \cdot 74$ & 11200 \\
\hline
\end{tabular}

ND, Not determined. 


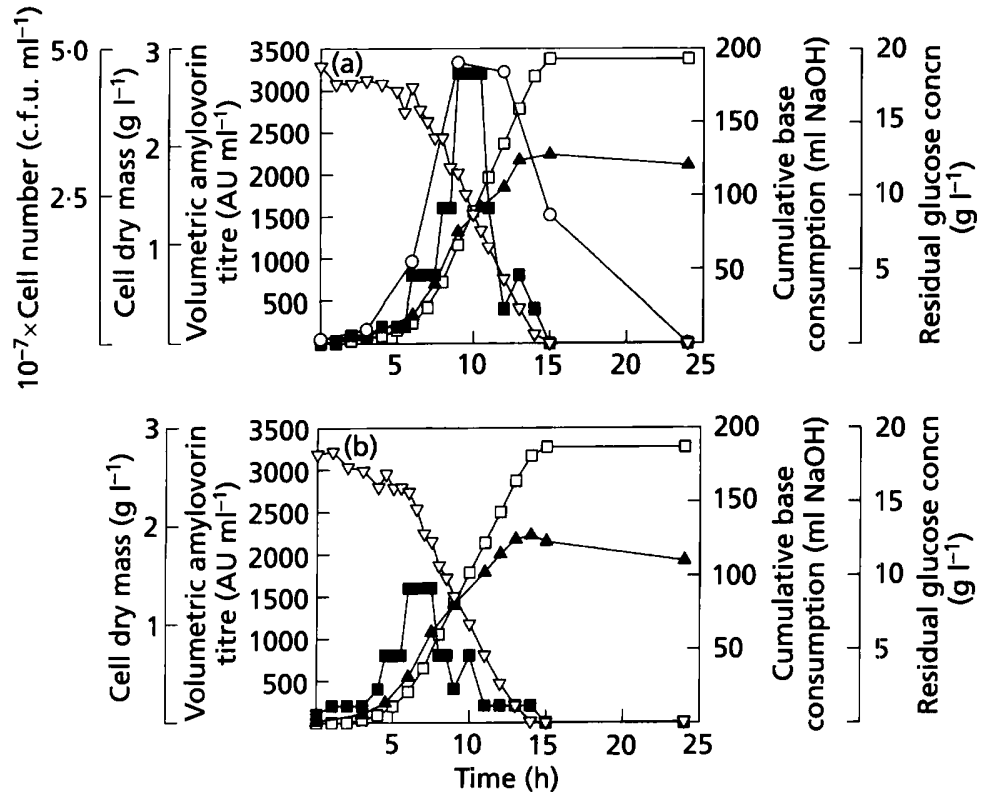

Fig. 6. Batch fermentation profile of $L$. amylovorus DCE 471 growth and amylovorin L471 production at constant $\mathrm{pH}$ of 5.0 and $37{ }^{\circ} \mathrm{C}$ with aeration at $40 \%$ (a) and $80 \%$ (b) air saturation levels. Cells were grown in a Biostat C fermenter containing 121 MRS broth with $20 \mathrm{~g}$ glucose $\mathrm{I}^{-1}$ as carbon source (see Methods). 0 , Cell numbers (only shown for $\mathbf{4 0} \%$ air saturation); $\Delta$, cell dry mass; $\square$. volumetric amylovorin L471 titre; $\nabla$, residual glucose concentration; $\square$, base consumption.

Table 3. Influence of the addition of sodium chloride and ethanol on L. amylovorus DCE 471 growth and amylovorin L471 production

Fermentations were carried out in $250 \mathrm{ml}$ Erlenmeyer flasks containing $100 \mathrm{ml}$ MRS broth. Samples were withdrawn after $12 \mathrm{~h}$ incubation.

\begin{tabular}{|c|c|c|c|}
\hline $\begin{array}{l}\text { Component added to } \\
\text { standard MRS broth }\end{array}$ & $\begin{array}{c}X \\
\left(\mathrm{~g} \mathrm{CDM} \mathrm{1}^{-1}\right)\end{array}$ & $\begin{array}{c}B \\
\left(\mathrm{AU} \mathrm{ml^{-1 }}\right)\end{array}$ & $\begin{array}{c}\times 10^{-6} Y_{p / x} \\
{\left[A U\left(g \mathrm{CDM}^{-1}\right]\right.}\end{array}$ \\
\hline None & $2 \cdot 19$ & 400 & $0 \cdot 18$ \\
\hline $\mathrm{NaCl}\left(5 \mathrm{~g} \mathrm{l}^{-1}\right)$ & $2 \cdot 10$ & 400 & $0 \cdot 19$ \\
\hline $\mathrm{NaCl}\left(10 \mathrm{~g} \mathrm{l}^{-1}\right)$ & $2 \cdot 05$ & 400 & $0 \cdot 19$ \\
\hline $\mathrm{NaCl}\left(20 \mathrm{~g} \mathrm{l}^{-1}\right)$ & 1.79 & 300 & $0 \cdot 17$ \\
\hline $\mathrm{NaCl}\left(30 \mathrm{~g} \mathrm{l}^{-1}\right)$ & 0.75 & 100 & $0 \cdot 13$ \\
\hline Ethanol $\left(10 \mathrm{ml} \mathrm{l}^{-1}\right)$ & $2 \cdot 16$ & 800 & $0 \cdot 37$ \\
\hline Ethanol $\left(20 \mathrm{ml} \mathrm{l}^{-1}\right)$ & $2 \cdot 12$ & 400 & $0 \cdot 19$ \\
\hline Ethanol $\left(30 \mathrm{ml} \mathrm{l}^{-1}\right)$ & $2 \cdot 05$ & 400 & $0 \cdot 19$ \\
\hline
\end{tabular}

and twofold higher initial glucose concentration (4.0\%), hence ensuring a sufficient supply of the energy source (glucose), building blocks (amino acids) and growth factors (e.g. vitamins), resulted in a much higher cell density (5.74 $\mathrm{g} \mathrm{CDM} \mathrm{l}^{-1}$; Table 2 ). The maximal amylovorin L471 activity then averaged $11200 \mathrm{AU} \mathrm{ml}^{-1}$ (Table 2 ) and was reached after $12 \mathrm{~h}$ of growth (data not shown). It corresponded with a biomass of about $4.70 \mathrm{~g} \mathrm{CDM}^{-1}$. The importance of unknown growth factors can also be concluded from the bacteriocin titres obtained with the semisynthetic media TGS and LHGS (Table 2).

\section{Effects of oxygen}

To investigate the influence of oxygen on growth and bacteriocin production, fermentations were run at 40 and $80 \%(\mathrm{v} / \mathrm{v})$ air saturation levels. The results are shown in Fig. 6. When fermentations were performed under aerobic conditions ( $40 \%$ air saturation), the cell growth, glucose consumption and bacteriocin production profiles were similar to those found in unaerated fermentations. Higher air saturation levels $(80 \%)$ did not affect either cell growth or glucose consumption. For instance, the cell yield coefficients were calculated as 0.17 and $0.14 \mathrm{~g}$ CDM (g glucose) $^{-1}$ at $40 \%$ and $80 \%$ air saturation, respectively. As with unfavourable growth temperatures, specific bacteriocin production increased with higher air saturation levels $\left[2.9 \times 10^{6}\right.$ and $3.6 \times 10^{6} \mathrm{AU}(\mathrm{g} \mathrm{CDM})^{-1}$ at $40 \%$ and $80 \%$ air saturation, respectively], despite the lower maximal bacteriocin titres $\left(3200\right.$ and $1600 \mathrm{AU} \mathrm{ml}^{-1}$ at $40 \%$ and $80 \%$ air saturation, respectively). Maximal specific growth rates were calculated as 0.45 and $0.53 \mathrm{~h}^{-1}$ at $40 \%$ and $80 \%$ air saturation, respectively.

\section{Effects of ethanol and $\mathrm{NaCl}$}

To determine if lower specific growth rates could cause the cells to display a higher specific bacteriocin production under environmental conditions not favouring microbial growth, the influence of added sodium chloride and 
ethanol were tested. The data are shown in Table 3. Increasing concentrations of both sodium chloride and ethanol inhibited cell growth and bacteriocin production. When ethanol (final concentration $10 \mathrm{mll}^{-1}$ ) was included in the growth medium, a twofold increase in the volumetric bacteriocin activity was observed. Specific bacteriocin production was also higher in the presence of ethanol $\left(10 \mathrm{ml} \mathrm{l}^{-1}\right)$. The lower values of $B$ and $Y_{p / x}$ shown in Table 3 are due to the late time (after peak activity) at which samples were withdrawn.

\section{DISCUSSION}

All the characteristics of amylovorin L471 production mentioned above clearly indicate that its biosynthesis displays primary metabolite kinetics. For several bacteriocins reported in the literature, it is indeed clear that the compound is produced during the exponential growth phase with a maximum in the middle or at the end of this phase, or at the beginning of the stationary phase (De Vuyst \& Vandamme, 1992; Parente et al., 1994; Mørtvedt-Abildgaard et al., 1995). Only in a few cases has bacteriocin production been shown to occur during the stationary phase (Kozak et al., 1978; Biswas et al., 1991; Jiménez-Díaz et al., 1993). In the case of lactostrepcin 3 (Kozak et al., 1978) and plantaricin T (Jiménez-Díaz $\epsilon$ t al., 1993), the compound is the second bacteriocin produced during the growth cycle. The production of a second bioactive peptide at a later time in the growth cycle may be the response to an environmental stimulus. Only Biswas et al. (1991) suggested that bacteriocins, particularly pediocin and nisin, are secondary metabolites, since they found that $60 \%$ of the pediocin $\mathrm{AcH}$ from $P$. acidilactici AcH was produced during the first $8 \mathrm{~h}$ (exponential phase), and the final $40 \%$ was produced during the next $8 \mathrm{~h}$ (stationary phase) of fermentation. In addition, Ten Brink et al. (1994) demonstrated production of acidocin B by non-growing cells of Lactobacillus acidophilus M46. In the latter case the inability of the cells to grow was caused by omitting Tween 80 from the medium. This manipulation may have resulted in a stress condition for the cells and hence overproduction of the bacteriocin (see below).

Whether bacteriocins have a vital function for the producing microorganism as is the case for primary metabolites is not yet known. It is, however, possible that bacteriocins do play some functional role during the growth cycle (Hurst, 1978; De Vuyst \& Vandarnme, 1992; De Vuyst, 1994). From a physiological point of view, it can be stated that bacteriocin inactivation in the stationary phase is compensated by continuous production of lactic acid at a constant rate. Indeed, lactic acid displays characteristics of both a primary and a secondary metabolite (Luedeking \& Piret, 1959). However, it is not clear if the disappearance of bacteriocin during the stationary phase is mainly due to proteolytic degradation. Adsorption of bacteriocin to the cell surface via ionic or hydrophobic interaction at $\mathrm{pH}$ values near neutrality and its desorption at low $\mathrm{pH}$ values may be an alternative explanation for the observed profile of the bacteriocin titre detected in the cell-free culture supernatant. Ad- sorption to the cells may for instance be the result of complex formation between the mature bacteriocin molecules and the immunity peptide. The latter is responsible for immunity of the cell to its own product during active growth. Both peptides are hydrophobic and bacteriocin immunity peptides indeed seem to be localized at the outer surface of the cytoplasmic membrane (Reis et al., 1994). Therefore, it may be advisable to follow both cellbound and extracellular bacteriocin during the fermentation course. Such an approach was followed during the early investigations of nisin production by Hurst (1966). However, a decrease in bacteriocin activity also occurs during fermentation runs at uncontrolled $\mathrm{pH}$ (De Vuyst \& Vandamme, 1992; L. De Vuyst, R. Callewaert \& B. Pot, unpublished results). Indeed, at the end of the fermentation the $\mathrm{pH}$ reached values which should favour bacteriocin desorption and hence a higher total bacteriocin activity should be detected in cell-free culture supernatants. However, the opposite was true. Finally, protein aggregation, for example via hydrophobic interactions between different polypeptide chains, cannot be completely ruled out.

Regarding a possible ecological role of bacteriocins, these compounds may offer a competitive advantage to the producing strains and help them in a competing microbial environment. This may underline their future use in mixed starter cultures for a directed and controllable fermentation, for instance in the production of olives, sauerkraut, sausages, etc. (Jiménez-Díaz et al., 1993; Harris et al., 1992b).

To harvest maximum bacteriocin levels it is advisable to collect the fermentation broth as soon as maximum activity is reached (De Vuyst \& Vandamme, 1992) or to carry out the fermentation under environmental conditions which prevent adsorption, such as a switch to $\mathrm{pH} 2.0$ (as shown here), or aggregation, for example by adding ethanol to the fermentation broth as suggested by Mørtvedt-Abildgaard et al. (1995). An alternative would be to remove the bacteriocin from the culture broth during fermentation by using appropriate adsorbents, either batchwise (Hörner et al., 1990; De Vuyst \& Vandamme, 1992) or continuously (L. De Vuyst, R. Callewaert \& B. Pot, unpublished results), or using a membrane reactor (Ungermann et al., 1991; De Vuyst \& Vandamme, 1992; Champagne et al., 1994). Apparently, the halt in bacteriocin production and the subsequent decrease in bacteriocin activity levels is accompanied by a decrease in cell numbers upon prolonged fermentation. However, based on our experimental data, we suggest that the decrease in cell number is not caused by cell death but has to do with bacteriocin adsorption to the cells. This adsorption phenomenon results in: (i) no further cell division after plating (only the cells whose surfaces are not occupied by bacteriocin molecules can produce new colonies); and (ii) no further bacteriocin biosynthesis by the cells owing to product inhibition. Only washed cells allow further growth and bacteriocin production. The latter has been shown by Ten Brink et al. (1994) who used non-growing $L$. acidophilus cells for bacteriocin production. 
Growth at low temperature results in low specific growth rates and high specific productivities. Slow growth can make more energy available for bacteriocin production; this energy is required for both polymerization of building blocks (amino acids) and specific and coordinated control of bacteriocin gene expression. The high ATP requirement for bacteriocin biosynthesis further underlines its primary metabolite nature. It may also explain why, in contrast with secondary metabolites (Martin, 1977), bacteriocin production is not repressed by phosphate, other than at very high inorganic phosphate concentrations, as has been shown for nisin (De Vuyst \& Vandamme, 1993). Apparently, bacteriocin production is stimulated by less favourable growth conditions, socalled stress factors, such as low temperatures, low specific growth rates, potentially toxic compounds such as sodium chloride, ethanol and oxygen, and a competing microflora, etc. Slow growth at low temperature indicates a stress condition and may explain the higher specific bacteriocin production. An extremely high concentration of the carbon source may also cause a stress situation owing to a higher osmotic pressure, and hence stimulate specific bacteriocin production. Ecologically, this may be explained by the fact that under unfavourable growth conditions the antagonistic effect of lower acid production is not sufficient for succesful competition with other microorganisms. Parente et al. (1994) also found that reduction in growth and lactic acid production is more than compensated by the increase in bacteriocin production. Mørtvedt-Abildgaard et al. (1995) further suggested that ethanol may induce genes involved in the synthesis of lactocin S. Thus, it is clear that manipulation of the cellular environment may stimulate bacteriocin production, or, more precisely, that lactic acid bacteria may react to physiological inducers. Recent studies indicate that bacteriocin production is controlled by an autoinduction regulatory mechanism through signal transduction. For instance, in the production of the lantibiotic nisin by Lactococcus lactis subsp. lactis, a two-component regulatory system encoded by the nis $\mathrm{R} K$ genes is involved in signal transducing (Engelke et al., 1994). The occurrence of a histidine kinase sensor protein and one or more response regulatory proteins has also been shown for subtilin (Klein et al., 1993), plantaricin A (Diep et al., 1994) and sakacin A (Axelsson \& Holck, 1995). For bacteriocin production, this cell-cell cooperative interaction or communication system employs either an antimicrobial peptide, e.g. carnobacteriocin (Saucier et al., 1995), a bacteriocin-like peptide, e.g. sakacin P (Tichaczek et al., 1994), or another peptide (Barefoot et al., 1994), as the signalling molecule. Because induction does not occur in the stationary phase, bacteriocins are considered to be primary metabolites of growth from this point of view too (Saucier et al., 1995). Apparently, a small amount of induction factor is necessary, since induction occurs from the early growth phase. On the other hand, glucose concentration and $\mathrm{pH}$ have been shown to affect the bacterial two-component signal-transducing system in Staphylococcus aureus (Regassa \& Betley, 1992; Regassa et al., 1992). In lactic acid bacteria too, nutritional and environmental control seem to play an important role in bacteriocin production (De Vuyst \& Vandamme, 1992, 1993; De Vuyst, 1995; Mørtvedt-Abildgaard et al., 1995). Alternatively, bacteriocin production could be the result of the induction of genes like those involved in the heat shock response in Escherichia coli or the cold shock response in psychrophilic microorganisms (Schlessinger et al., 1982; Van Bogelen et al., 1987).

The fact that slower growth favours a higher bacteriocin production is of practical importance on an industrial scale, since metabolic regulatory mechanisms such as catabolite repression and feedback-inhibition may be circumvented by a slow feeding rate of the substrate responsible which in turn results in a slower growth regime. Slow feeding may be controlled by fed-batch and continuous culture fermentations. The stimulation of bacteriocin production by unfavourable growth conditions may be of further importance when bacteriocinproducing lactic acid bacteria are added to foods as starters or protective cultures. However, the specific environment of the food may limit not only the capacity of strains to produce antimicrobials but also the antagonistic effect of secreted or added bacteriocins. The presence of salts and other food ingredients, adsorption to proteins and other food particles, unequal distribution of the bacteriocin molecules in the food water phase, etc. may explain both phenomena.

Our results show that production of active bacteriocin may be severely affected by environmental factors. In view of the possible future use of bacteriocins as food and feed biopreservatives, these factors have to be taken into account in the design of bacteriocin production processes.

\section{ACKNOWLEDGEMENTS}

Part of the research presented in this paper was financially supported by the Research Council of the Vrije Universiteit Brussel, the Belgian National Fund for Scientific Research, and the Biotechnology Programme of the Commission of the European Community (grants BIO2-CT943055 and ERBCIPACT-940160).

\section{REFERENCES}

Axelsson, L. \& Holck, A. (1995). The genes involved in production of and immunity to sakacin A, a bacteriocin from Lactobacillus sake Lb706. J Bacteriol 177, 2125-2137.

Barefoot, S. F. \& Klaenhammer, T. R. (1984). Purification and characterization of the Lactobacillus acidophilus bacteriocin lactacin B. Antimicrob Agents Chemother 26, 328-334.

Barefoot, S. F., Chen, Y.-R., Hughes, T. A., Bodine, A. B., Shearer, M. Y. \& Hughes, M. D. (1994). Identification and purification of a protein that induces production of the Lactobacillus acidopbilus bacteriocin lactacin B. Appl Environ Microbiol 60, 3522-3528.

Biswas, S. R., Ray, P., Johnson, M. C. \& Ray, B. (1991). Influence of growth conditions on the production of a bacteriocin, pediocin $\mathrm{AcH}$, by Pediococcus acidilactici H. Appl Environ Microbiol 57, 1265-1267.

Champagne, C. P., Lacroix, C. \& Sodini-Gallot, I. (1994). Immobilized cell technologies for the dairy industry. Crit Rev Biotechnol 14, 109-134.

Daba, H., Lacroix, C., Huang, J. \& Simard, R. E. (1993). Influence of growth conditions on production and activity of mesenterocin 5 by 
a strain of Leuconostoc mesenteroides. Appl Microbiol Biotechnol 39, 166-173.

De Vuyst, L. (1994). Nisin production variability between natural Lactococcus lactis subsp. lactis strains. Biotechnol Lett 16, 287-292.

De Vuyst, L. (1995). Nutritional factors affecting nisin production by Lactococcus lactis subsp. lactis NIZO 22186 in a synthetic medium. $J$ Appl Bacteriol 78, 28-33.

De Vuyst, L. \& Vandamme, E. J. (1992). Influence of the carbon source on nisin production in Lactococcus lactis subsp. lactis batch fermentations. J Gen Microbiol 138, 571-578.

De Vuyst, L. \& Vandamme, E. J. (1993). Influence of the phosphorus and nitrogen source on nisin production in Lactococcus lactis subsp. lactis batch fermentations using a complex medium. Appl Microbiol Biotechnol 40, 17-22.

De Vuyst, L. \& Vandamme, E. J. (1994a). Bacteriocins of Lactic Acid Bacteria: Microbiology, Genetics and Applications. London: Blackie Academic \& Professional.

De Vuyst, L. \& Vandamme, E. J. (1994b). Antimicrobial potential of lactic acid bacteria. In Bacteriocins of Lactic Acid Bacteria: Microbiology, Genetics and Applications, pp. 91-142. Edited by L. De Vuyst \& E. J. Vandamme. London: Blackie Academic \& Professional.

Diep, D. B., Håvarstein, L. S., Nissen-Meyer, J. \& Nes, I. F. (1994). The gene encoding plantaricin A, a bacteriocin from Lactobacillus plantarum $\mathrm{C} 11$, is located on the same transcription unit as an agrlike regulatory system. Appl Environ Microbiol 60, 160-166.

Dodd, H. M. \& Gasson, M. J. (1994). Bacteriocins of lactic acid bacteria. In Genetics and Biotechnology of Lactic Acid Bacteria, pp. 211-251. Edited by M. J. Gasson \& W. M. De Vos. London: Blackie Academic \& Professional.

Egorov, N. S., Baranova, I. P. \& Kozlova, Y. I. (1971). Optimization of nutrient medium composition for the production of the antibiotic nisin by Streptococcus lactis. Mikerobiologiya 40, 993-998.

Engelke, G., Gutowski-Eckel, Z., Kiesau, P., Siegers, K., Hammelmann, M. \& Entian, K.-D. (1994). Regulation of nisin biosynthesis and immunity in Lactococcus lactis 6F3. Appl Environ Microbiol 60, 814-825.

Harris, L. J., Fleming, H. P. \& Klaenhammer, T. R. (1992a). Characterization of two nisin-producing Lactococcus lactis subsp. lactis strains isolated from a commerical sauerkraut fermentation. Appl Environ Microbiol 58, 1477-1483.

Harris, L. J., Fleming, H. P. \& Klaenhammer, T. R. (1992b). Novel paired starter culture system for sauerkraut, consisting of a nisinresistant Leuconostoc mesenteroides strain and a nisin-producing Lactococcus lactis strain. Appl Environ Microbiol 58, 1484-1489.

Hirsch, A. (1951). Growth and nisin production of a strain of Streptococcus lactis. J Gen Microbiol 5, 208-221.

Hoover, D. \& Steenson, L. (1993). Bacteriocins of Lactic Acid Bacteria. New York: Academic Press.

Hörner, T., Ungermann, V., Zăhner, H., Fiedler, H.-P., Utz, R., Kellner, R. \& Jung, G. (1990). Comparative studies on the fermentative production of lantibiotics by staphylococci. Appl Microbiol Biotechnol 32, 511-517.

Hurst, A. (1966). Biosynthesis of the antibiotic nisin by whole Streptococcus lactis organisms. J Gen Microbiol 44, 209-220.

Hurst, A. (1978). Nisin: its preservative effect and function in the growth cycle of the producer organism. In Streptococci, pp. 297-314. Edited by F. A. Skinner \& L. B. Quesnel. London: Academic Press.

Hurst, A. (1981). Nisin. Adv Appl Microbiol 27, 85-123.
Jiménez-Dlaz, R., Rios-Sánchez, R. M., Desmazeaud, M., RuizBarba, J. L. \& Piard, J.-C. (1993). Plantaricins S and T, two new bacteriocins produced by Lactobacillus plantarum LPCO10 isolated from a green olive fermentation. Appl Environ Microbiol 59, 1416-1424.

Joerger, M. C. \& Klaenhammer, T. R. (1986). Characterization and purification of helveticin $\mathrm{J}$ and evidence for a chromosomally determined bacteriocin produced by Lactobacillus belveticus 481 . J Bacteriol 167, 439-446.

Kaiser, A. L. \& Montville, T. J. (1993). The influence of $\mathrm{pH}$ and growth rate on production of the bacteriocin, bavaricin $\mathrm{MN}$, in batch and continuous fermentations. $J$ Appl Bacteriol 75, 536-540.

Klaenhammer, T. R. (1988). Bacteriocins of lactic acid bacteria. Biocbimie 70, 337-349.

Klaenhammer, T. R. (1993). Genetics of bacteriocins produced by lactic acid bacteria. FEMS Microbiol Rev 12, 39-85.

Klein, C., Kaletta, C. \& Entian, K.-D. (1993). Biosynthesis of the lantibiotic subtilin is regulated by a histidine kinase/response regulator system. Appl Environ Microbiol 59, 296-303.

Kleinkauf, H., von Döhren, H., Dornauer, H. \& Nesemann, G. (1986). Regulation of Secondary Metabolite Formation. Weinheim: $\mathrm{VCH}$.

Kondo, S., Yasui, K., Natsume, M., Katayama, M. \& Marumo, S. (1988). Isolation, physico-chemical properties and biological activity of pamamycin-607, an aerial mycelium-inducing substance from Streptomyces alboniger. J Antibiot 9, 1196-1204.

Kozak, W., Bardowski, J. \& Dobrzanski, W. T. (1978). Lactostrepcins - acid bacteriocins produced by lactic streptococci. $J$ Dairy Res 45, 247-257.

Kozlova, Yu. I., Egorov, N. S., Baranova, I. P. \& Maksimov, V. N. (1972). Metabolic kinetics of Streptococcus lactis on initial and optimal media. Mikrobiologiya 41, 1007-1012.

Luedeking, R. \& Piret, E. L. (1959). A kinetic study of the lactic acid fermentation batch process at controlled $\mathrm{pH}$. $J$ Biochem Microbiol Technol Eng 1, 393-412.

Martin, J. F. (1977). Control of antibiotic biosynthesis by phosphate. Adv Biochem Eng 6, 105-127.

Mayr-Harting, A., Hedges, A. J. \& Berkeley, R. C. W. (1972). Methods for studying bacteriocins. Meth Microbiol 7, 315-422.

Mørtvedt-Abildgaard, C. I., Nissen-Meyer, J., Jelle, B., Grenov, B., Skaugen, M. \& Nes, I. F. (1995). Production and pH-dependent bactericidal activity of lactocin S, a lantibiotic from Lactobacillus sake L45. Appl Environ Microbiol 61, 175-179.

Muriana, P. M. \& Klaenhammer, T. R. (1987). Conjugal transfer of plasmid-encoded determinants for bacteriocin production and immunity in Lactobacillus acidopbilus 88. Appl Environ Microbiol 53, 553-560.

Parente, E. \& Hill, C. (1992). A comparison of factors affecting the production of two bacteriocins from lactic acid bacteria. J Appl Bacteriol 73, 290-298.

Parente, E. \& Ricciardi, A. (1994). Influence of $\mathrm{pH}$ on the production of enterocin 1146 during batch fermentation. Lett Appl Microbiol 19, 12-15.

Parente, E., Ricciardi, A. \& Addario, G. (1994). Influence of $\mathrm{pH}$ on growth and bacteriocin production by Lactococcus lactis subsp. lactis 140 NWC during batch fermentation. Appl Microbiol Biotechnol 41, 388-394.

Piard, J.-C. \& Desmazeaud, M. J. (1991). Inhibiting factors produced by lactic acid bacteria. 1. Oxygen metabolites and catabolism end-products. Lait 71, 525-541.

Piard, J.-C. \& Desmazeaud, M. J. (1992). Inhibiting factors 
produced by lactic acid bacteria. 2. Antibacterial substances and bacteriocins. Lait 72, 113-142.

Quadri, L. E. N., Sailer, M., Roy, K. L., Vederas, J. C. \& Stiles, M. E. (1994). Chemical and genetic characterization of bacteriocins produced by Carnobacterium piscicola LV17B. J Biol Chem 269, 12204-12211.

Ray, B. \& Daeschel, M. (1992). Food Biopreservatives of Microbial Origin. Florida: CRC Press.

Regassa, L. B. \& Betley, M. J. (1992). Alkaline $\mathrm{pH}$ decreases expression of the accessory gene regulator (agr) in Stapbylococcus aureus. J Bacteriol 174, 5095-5100.

Regassa, L. B., Novick, R. P. \& Betley, M. J. (1992). Glucose and nonmaintained $\mathrm{pH}$ decrease expression of the accessory gene regulator (agr) in Stapbylococcus aureus. Infect Immun 60, 3381-3388.

Reis, M., Eschbach-Bludau, M., Iglesias-Wind, M. I., Kupke, T. \& Sahl, H.-G. (1994). Producer immunity towards the lantibiotic Pep5: identification of the immunity gene $p e p \mathrm{I}$ and localization and functional analysis of its gene product. Appl Environ Microbiol 60, 2876-2883.

Saucier, L., Poon, A. \& Stiles, M. E. (1995). Induction of bacteriocin in Carnobacterium piscicola LV17. J Appl Bacteriol 78, 684-690.

Schlessinger, M., Ashburner, M. \& Tissieres, A. (1982). Heat Shock: from Bacteria to Man. New York: Cold Spring Harbor.

Smith, J. (1993). Technology of Reduced-Additive Foods. London: Blackie Academic \& Professional.
Ten Brink, B., Minekus, M., van der Vossen, J. M. B. M., Leer, R. J. \& Huis in 't Veld, J. H. J. (1994). Antimicrobial activity of lactobacilli: preliminary characterization and optimization of production of acidocin $\mathrm{B}$, a novel bacteriocin produced by Lactobacillus acidopbilus M46. J Appl Bacteriol 77, 140-148.

Tichaczek, P. S., Vogel, R. F. \& Hammes, W. P. (1994). Cloning and sequencing of sakP encoding sakacin $\mathrm{P}$, the bacteriocin produced by Lactobacillus sake LTH 673. Microbiology 140, 361-367.

Ungermann, V., Goeke, K., Fiedler, H.-P. \& Zähner, H. (1991). Optimization of fermentation and purification of gallidermin and epidermin. In Nisin and Novel Lantibiotics, pp. 410-421. Edited by G. Jung \& H.-G. Sahl. Leiden: ESCOM Science.

Vandamme, E. J. (1981). Properties, biogenesis and fermentation of the cyclic decapeptide antibiotic gramicidin S. In Topics in Enzyme and Fermentation Biotecbnology, pp. 187-261. Edited by A. Wiseman. Chichester: Ellis Horwood.

Van Bogelen, R. A., Kelley, P. M. \& Neidhardt, F. C. (1987). Differential induction for heat-shock, SOS, and oxidation-stress regulons and accumulation of nucleotides in Escherichia coli. $J$ Bacteriol 169, 26-32.

Yang, R., Johnson, M. C. \& Ray, B. (1992). Novel method to extract large amounts of bacteriocins from lactic acid bacteria. Appl Environ Microbiol 58, 3355-3359.

Received 3 August 1995; revised 12 December 1995; accepted 15 December 1995. 